\title{
Influenza vaccination in patients with diabetes: disparities in prevalence between African Americans and Whites
}

\author{
Liqa N. ATHAMNEH, Sujit S. SANSGIRY. \\ Received (first version): 7-Jan-2014 Accepted: 11-May-2014
}

\begin{abstract}
${ }^{*}$
Background: Patients with diabetes who contract influenza are at higher risk of complications, such as hospitalization and death. Patients with diabetes are three times more likely to die from influenza complications than those without diabetes. Racial disparities among patients with diabetes in preventive health services have not been extensively studied.

Objective: To compare influenza vaccination rates among African Americans and Whites patients with diabetes and investigate factors that might have an impact on racial disparities in the receipt of influenza vaccinations. Methods: A secondary data analysis of 47,283 (unweighted) patients with diabetes from the 2011 Behavioral Risk Factor Surveillance System survey (BRFSS) $(15,902,478$ weighted) was performed. The survey respondents were asked whether they received an influenza vaccination in the last twelve months. We used logistic regression to estimate the odds of receiving the influenza vaccine based on race.

Results: The results indicated a significantly lower proportion of African Americans respondents (50\%) reported receiving the influenza vaccination in the last year when compared with Whites respondents (61\%). Age, gender, education, health care coverage, health care cost, and employment status were found to significantly modify the effect of race on receiving the influenza vaccination. Conclusions: This study found a significant racial disparity in influenza vaccination rates in adults with diabetes with higher rates in Whites compared to African Americans individuals. The public health policies that target diabetes patients in general and specifically African Americans in the 65+ age group, women, and homemakers, may be necessary to diminish the racial disparity in influenza vaccination rates between African Americans and Whites diabetics.
\end{abstract}

Keywords: Influenza Vaccines; Vaccination; Diabetes Mellitus; Healthcare Disparities; Ethnic Groups; Health Promotion; Health Care Surveys; United States

Liqa N. ATHAMNEH. Institute of Community Health, University of Houston, Texas Medical Center. Houston, TX (United States). lathamne@uh.edu

Sujit S. SANSGIRY. Institute of Community Health, University of Houston, Texas Medical Center. Houston, TX (United States).ssansgiry@uh.edu

\section{INTRODUCTION}

Every year, approximately $5-20 \%$ of United States (US) residents develop influenza. ${ }^{1}$ More than 200,000 patients are hospitalized with flu-related complications $^{1}$ and an average of 24,000 deaths result from influenza infection. ${ }^{2}$ In the US the annual cost of influenza epidemics was estimated to be about 71-167 billion dollars ${ }^{3}$ with about ten billion dollars associated with direct medical cost each year. $^{4}$

While most Americans develop an uncomplicated illness from the flu infection, patients with diabetes are at higher risk of severe disease and complications, such as hospitalization or death, as a result of developing influenza. ${ }^{5}$ Actually, patients with diabetes are three times more likely to die from flu complications than those without diabetes ${ }^{6}$, and it has been highly recommended by the Centers for Disease Control \& Prevention (CDC) that patients with diabetes who are 6 months or older receive an influenza vaccine. ${ }^{5}$

Efforts have increased over the past twenty years to reduce health disparities in the US. ${ }^{7}$ Healthy People 2020 set the goal of eliminating health disparities as well as targeting an influenza vaccination rate of $90 \%$ for high-risk non-institutionalized adults aged 18 to $64{ }^{8}$ Studies have reported racial disparities in influenza vaccination. ${ }^{9,10}$ According to a study that examined the racial and ethnic differences in vaccination among patients with diabetes in 2003, Whites had higher vaccination rates than African Americans. ${ }^{11}$ The same study reported that racial disparity in vaccination rates for adults with diabetes is independent of access to care, health care coverage, and socioeconomic status. ${ }^{11}$ While an Irish study found that increasing age, duration of diabetes, and history of visiting a general practitioner (GP) significantly increased the frequency of influenza vaccination over a five-year period. $^{12}$

To our knowledge, no studies have been conducted in the last ten years to observe the racial and ethnic differences in influenza vaccinations, specifically among patients with diabetes in the US. The main objectives for this research were to examine racial disparities in influenza vaccination among patients with diabetes in the US, and understand factors that might have an impact on racial disparities such as age, gender, education, general health, income level, employment status, marital status, smoking status, having a health provider, not being able to see a doctor due to cost, and having health care coverage. We compared influenza vaccine 
coverage in African Americans and Whites patients with diabetes using data from the 2011 Behavioral Risk Factor Surveillance System (BRFSS). ${ }^{13}$

\section{METHODS}

\section{Study Sample}

The BRFSS is administered and overseen by the CDC Behavioral Risk Factor Surveillance Branch. BRFSS is an ongoing data collection program that is designed to measure behavioral risk factors, health-related perceptions, disease conditions, and behaviors among adults (18 years of age or older) in the US, It is carried out every year by all 50 states, the District of Columbia and the U.S. Territories of Guam, Puerto Rico, and the Virgin Islands.

The 2011 BRFSS data were collected from a random sample of adults (one per household) through a telephone survey, of non-institutionalized adult individuals, living in households with a landline or cell phone (in the Virgin Islands the sample was collected from landlines-only respondents). Households were selected by disproportionate stratified random sampling in fifty-one regions and by simple random sample design in Guam, Puerto Rico, and the U.S. Virgin Islands. One adult per household was eligible to respond. ${ }^{14}$

In 2011, data were collected from 450,285 respondents who lived in the 50 states and 4 regions. The median response rate for interviews from all states and Washington, DC, was $49.72 \%$. 14 Started in 1984, BRFSS is the longest ongoing phone survey in the world. The BRFSS dataset is available to the public through the CDC website (http://www.cdc.gov/brfss/annual_data/annual_2011 .htm). This study was approved by the Committees for the Protection of Human Subjects at the University of Houston.

\section{Study variables}

Data from the 2011 questionnaire were used to define the study sample, exposure variable, and outcome variable. To identify diabetics in our study, we used the standard BRFSS question, in which respondents were asked if they had "ever been told by a doctor, nurse, or other health professional that [they] had diabetes," Respondents who answered "yes" to the question were included in our sample of patients with diabetes.

The BRFSS included questions that identify race. Those who answered White or African Americans were included. Those who answered any race other than White or African Americans or refused to answer or indicated that they did not know or were not sure of their race were excluded from the study sample. We identified respondents who had received the influenza vaccine by the standard BRFSS question, "during the last 12 months have you had a flu shot." Those who answered, "Yes," or "No," were included, while those that answered "don't know," "not sure," or "refused" were excluded from the analysis.
The following independent predictor variables were included in our analyses: age by 5 categories (18$34,35-44,45-54,55-64$, or 65+ years); gender (male or female); education with two-level variables (up to high school graduate or some college/college graduate and higher); general health status (excellent, very good, good, fair, or poor); health care coverage (yes or no); has a health care provider (yes or no); could not see a doctor due to cost in last 12 months (yes or no); time since last routine check-up (within the last 12 months vs. one year or more); smoking status (everyday, or some days, or not at all); marital status (married, divorced, widowed, separated, never married, a member of an unmarried couple); employment status (employed for wages, self-employed, out of work for more than 1 year, out of work for less than 1 year, a homemaker, a student, retired, unable to work); the annual household income level (less than 10,000, $10,000-15,000, \quad 15,000-20,000, \quad 20,000-25,000$, $25,000-35,000,35,000-50,000,50,000-75,000$, and more than 75,000 ) .

\section{Statistical analysis}

SAS $9.2 \AA$ (SAS Institute Inc., Carey, North Carolina) was used to perform the statistical analyses for this study and adjustments were made for the raking procedure and for the sampling design used in BRFSS 2011. Frequencies were compared both by race and by receiving the flu vaccine using a chi-square analysis. A three-step procedure was used to identify potential confounders or effect modifiers. The first step was to compute the crude bivariate association between our outcome variable, receipt of immunization (yes vs. no), and each of our exposure variables.

The second step was to repeat the bivariate analyses after adjusting for one additional covariate added as a categorical variable (age, has a health care provider, sex, education, marital status, health care coverage, general health status, time since last routine check-up, could not see a doctor due to cost in last 12 months, annual income level, employment status and smoking status). The categorical variables were compared using the Breslow-Day test to determine if the additional covariate is a potential confounder or a potential effect modifier. Gender, health care coverage, not being able to see the doctor due to cost in the last 12 months, age, education level, and employment status were found to significantly modify the effect of race on vaccine status. The odds of receiving influenza vaccination in African Americans when compared with Whites were reported in the final analysis for each level of the detected effect modifier.

The third step was to compare the crude odds ratio (OR) with the adjusted OR, using the MantelHaensel OR, for the potential confounders detected in the second step. None of the covariates tested in this step had a Mantel-Haensel OR of $10 \%$ or more; confounders were not detected in this study.

The logistic regression analysis was stratified for all the variables identified as effect modifiers one variable at a time. And since no confounders were found in this study the logistic regression for each 


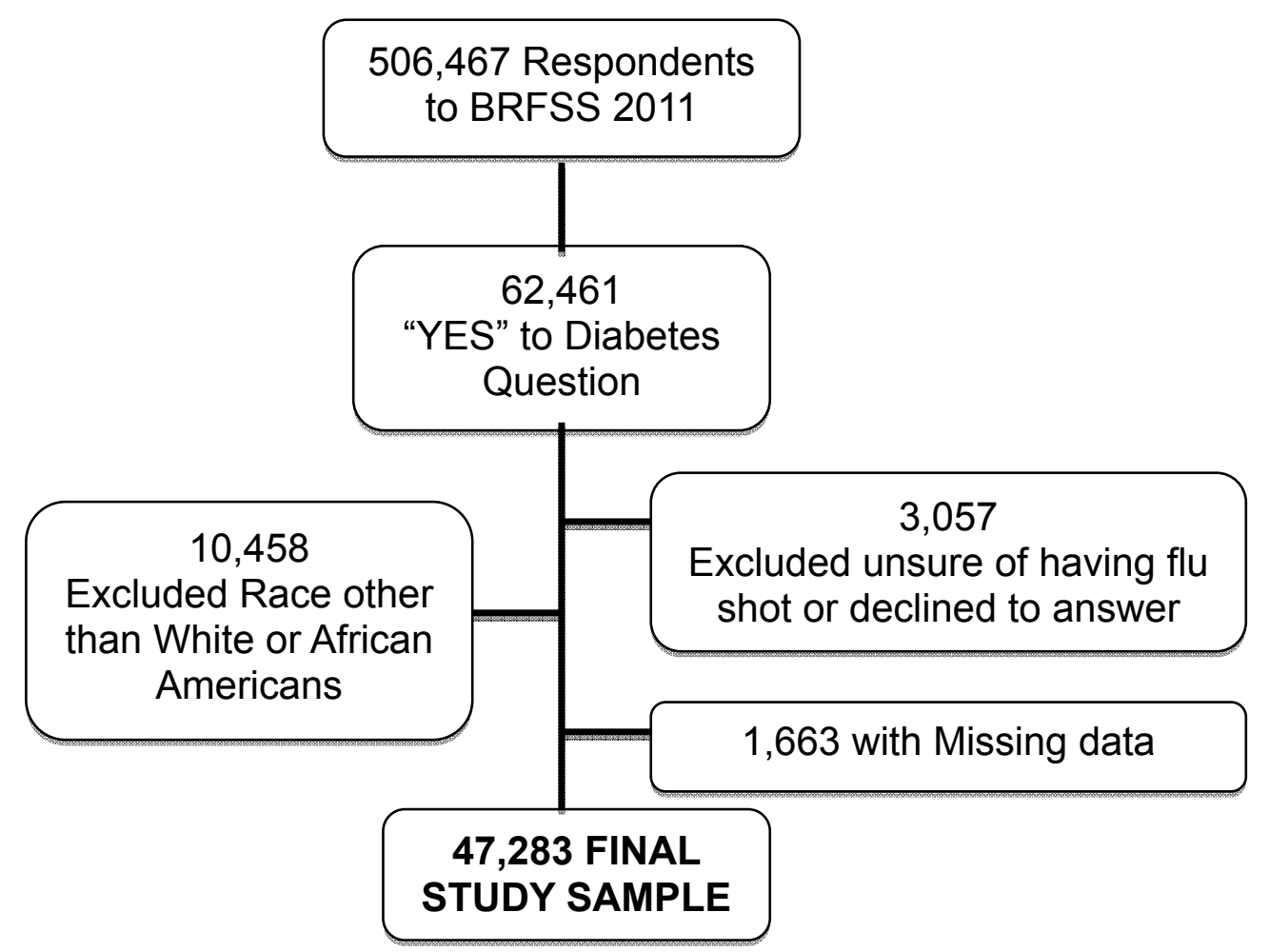

Figure 1. Study sample of diabetes patient respondents to the 2011 Behavioral Risk Factor Surveillance System Questionnaire.

variable with the receipt of influenza vaccination did not control for any other variables.

The OR and $95 \%$ confidence intervals were reported for the receipt of influenza vaccination in the last 12 months among African Americans and Whites patients with diabetes (table 3 ). ${ }^{15}$

\section{RESULTS}

The number of adults who responded to the BRFSS survey in 2011 was 506,467. A total of 62,461 $(8.1 \%)$ reported that they had been told that they had diabetes by a health professional. Figure 1 diagrams subjects excluded to arrive at the 47,283 (unweighted) respondents included in the study $(15,902,478$ weighted).

Gender, health care coverage, not being able to see the doctor due to cost in the last 12 months, age, education level, and employment status were found to significantly modify the effect of race on vaccine status according to Breslow-day test results $(p<0.10$, indicating heterogeneity). None of the remaining covariates (Income, last routine checkup, marital status, general health, smoking status and having a health care provider) had a difference between crude OR and Mantel-Haensel OR of $10 \%$ or more; confounders were not detected in this study.

Table 1 provides the distribution of the sample. The study sample consisted mainly of White patients $(85 \%, n=40,240)$, females $(58 \%, n=27,700)$, married $(48 \%, n=22,631)$, retired $(46 \% n=21,839)$, and from the oldest $(65+)$ age group $(52 \%$, $n=24,749)$.
The White group had a higher percentage of college or more degree holders $(54 \%, n=21,733$ in Whites vs. $41 \%, n=2,950$ in African Americans); more nonsmoker participants $(75 \% \mathrm{n}=16,076$ in Whites vs. $64 \%, n=2,123$ in African Americans); higher ratio of those who had a health care provider $(96 \%$, $n=38,810$ in Whites vs. $93 \%, n=6,576$ in African Americans); more participants reported having health insurance $(94 \%, n=37,775$ in Whites vs. $89 \%, n=6,244$ in African Americans); better reported health status with higher percentage of respondents reporting excellent, very good, or good health status $(58 \%, n=23,332$ in Whites vs. $46 \%, n=3,260$ in African Americans); and higher annual income levels (25,000 a year or more).

A greater proportion of African Americans responders were found to have reported a routine check-up in the last 12 months $(92 \%, n=6,471$ in African Americans vs. $87 \%, n=35,127$ in Whites); to be twice as likely to have indicated they had not been able to see a doctor in the last 12 months due to cost $(20 \%, n=1,379$ in African Americans vs. $11 \%, n=4,398$ in Whites); and a higher percentage of participants in the lower annual income levels $(25,000$ a year or less).

Overall, the influenza vaccination coverage rate among this study sample of diabetes patients was $60 \%, n=28,448$ (Table 2). The rate for influenza vaccination, as self-reported by the respondents, increased significantly as age increased, from only $39 \%(n=307)$ among respondents aged $18-34$ to $66 \%(n=16,399)$ of those aged 65 and older. Influenza vaccination was higher among women $(61 \%, n=16,858)$, Whites $(62 \%, n=24,915)$, who had a college or more education $(62 \%, n=15,327)$, the 


\begin{tabular}{|c|c|c|c|c|c|}
\hline \multicolumn{2}{|c|}{ Characteristic } & $\begin{array}{c}\text { Total } \\
n=47,283\end{array}$ & $\begin{array}{c}\text { Whites } \\
n=40,240\end{array}$ & $\begin{array}{c}\text { African Americans } \\
n=7,043\end{array}$ & $\begin{array}{c}\text { Chi-square } \\
p \text {-value }\end{array}$ \\
\hline Age & $\begin{array}{r}18-34 \\
35-44 \\
45-54 \\
55-65 \\
65+\end{array}$ & $\begin{array}{c}780(01.65) \\
2,081(04.40) \\
6,213(13.14) \\
13,460(28.47) \\
24,749(52.34)\end{array}$ & $\begin{array}{c}611(01.52) \\
1,667(04.14) \\
5,026(12.50) \\
11,215(27.88) \\
21,706(53.96)\end{array}$ & $\begin{array}{c}168(02.39) \\
414(05.88) \\
1,185(16.83) \\
2,241(31.82) \\
3,035(43.09) \\
\end{array}$ & $<0.001$ \\
\hline Gender & $\begin{array}{r}\text { Male } \\
\text { Female }\end{array}$ & $\begin{array}{l}19,583(41.42) \\
27,700(58.58)\end{array}$ & $\begin{array}{l}17,495(43.48) \\
22,745(56.52)\end{array}$ & $\begin{array}{l}2,088(29.65) \\
4,955(70.35)\end{array}$ & $<0.001$ \\
\hline Education & $\begin{array}{r}\text { High school graduate or less } \\
\text { Some collage or more }\end{array}$ & $\begin{array}{l}22,600(47.80) \\
24,683(52.20)\end{array}$ & $\begin{array}{l}18,507(45.99) \\
21,733(54.01)\end{array}$ & $\begin{array}{l}4,093(58.11) \\
2,950(41.89)\end{array}$ & $<0.001$ \\
\hline General health & $\begin{array}{r}\text { Excellent } \\
\text { Very good } \\
\text { Good } \\
\text { Fair } \\
\text { Poor }\end{array}$ & $\begin{array}{c}1,349(02.85) \\
7,624(16.12) \\
17,619(37.26) \\
13,523(28.60) \\
7,167(15.16)\end{array}$ & $\begin{array}{c}1,162(02.89) \\
6,883(17.11) \\
15,287(37.99) \\
10,965(27.25) \\
5,942(14.77)\end{array}$ & $\begin{array}{c}187(02.66) \\
741(10.52) \\
2,332(33.11) \\
2,558(36.32) \\
1,225(17.39) \\
\end{array}$ & $<0.001$ \\
\hline $\begin{array}{l}\text { Health care } \\
\text { coverage }\end{array}$ & $\begin{array}{r}\text { Yes } \\
\text { No } \\
\end{array}$ & $\begin{array}{c}44,019(93.10) \\
3,264(06.90)\end{array}$ & $\begin{array}{c}37,775(93.87) \\
2,465(6.13)\end{array}$ & $\begin{array}{c}6,244(88.66) \\
799(11.34) \\
\end{array}$ & $<0.001$ \\
\hline $\begin{array}{l}\text { Has a health care } \\
\text { provider }\end{array}$ & $\begin{array}{r}\text { Yes } \\
\text { No }\end{array}$ & $\begin{array}{c}45,396(96.01) \\
1,887(3.99) \\
\end{array}$ & $\begin{array}{c}38,810(96.47) \\
1,420(3.53)\end{array}$ & $\begin{array}{c}6,576(93.37) \\
467(6.63) \\
\end{array}$ & $<0.001$ \\
\hline $\begin{array}{l}\text { Could not see a } \\
\text { doctor in last } 12 \\
\text { months due to cost }\end{array}$ & $\begin{array}{l}\text { Yes } \\
\text { No }\end{array}$ & $\begin{array}{c}5,777(12.22) \\
41,506(87.78)\end{array}$ & $\begin{array}{c}4,398(10.93) \\
35,842(89.07)\end{array}$ & $\begin{array}{l}1,379(19.58) \\
5,664(80.42)\end{array}$ & $<0.001$ \\
\hline $\begin{array}{l}\text { Last routine Check } \\
\text { up }\end{array}$ & $\begin{array}{r}<12 \text { months } \\
>=1 \text { year }\end{array}$ & $\begin{array}{c}41,598(87.98) \\
5,675(12.02)\end{array}$ & $\begin{array}{c}35,127(87.29) \\
5,113(12.71)\end{array}$ & $\begin{array}{c}6,471(91.88) \\
572(8.12) \\
\end{array}$ & $<0.001$ \\
\hline Smoking status & $\begin{array}{r}\text { Everyday } \\
\text { Some days } \\
\text { Not at all }\end{array}$ & $\begin{array}{c}5,049(20.36) \\
1,555(6.27) \\
18,199(73.37)\end{array}$ & $\begin{array}{c}4,313(20.04) \\
1,130(5.25) \\
16,076(74.71)\end{array}$ & $\begin{array}{c}736(22.42) \\
425(12.94) \\
2,123(64.65) \\
\end{array}$ & $<0.001$ \\
\hline Marital status & $\begin{array}{r}\text { Married } \\
\text { Divorced } \\
\text { Widowed } \\
\text { Separated } \\
\text { Never married } \\
\text { Member of unmarried couple }\end{array}$ & $\begin{array}{c}22,631(47.86) \\
7,919(16.75) \\
10,588(22.39) \\
1,149(02.43) \\
4,454(09.42) \\
542(01.15) \\
\end{array}$ & $\begin{array}{c}20,590(51.17) \\
6,425(15.97) \\
8,898(22.11) \\
652(01.62) \\
3,204(07.96) \\
471(01.17) \\
\end{array}$ & $\begin{array}{l}2,041(28.98) \\
1,494(21.21) \\
1,690(24.00) \\
497(07.06) \\
1,250(17.75) \\
71(01.01) \\
\end{array}$ & $<0.001$ \\
\hline $\begin{array}{l}\text { The annual income } \\
\text { level }\end{array}$ & $\begin{array}{r}\text { Less than } 10000 \\
10000-15000 \\
15000-20000 \\
20000-25000 \\
25000-35000 \\
35000-50000 \\
50000-75000 \\
\text { More than } 75000\end{array}$ & $\begin{array}{l}3,252(06.88) \\
4,221(08.93) \\
4,647(09.83) \\
5,246(11.10) \\
5,809(12.29) \\
6,196(13.11) \\
5,327(11.27) \\
6,095(12.89)\end{array}$ & $\begin{array}{l}2,245(05.58) \\
3,320(08.25) \\
3,686(09.16) \\
4,438(11.03) \\
5,020(12.48) \\
5,518(13.72) \\
4,859(12.08) \\
5,644(14.03)\end{array}$ & $\begin{array}{l}1,007(14.30) \\
901(12.79) \\
961(13.64) \\
808(11.47) \\
789(11.20) \\
678(09.63) \\
468(06.64) \\
451(06.40)\end{array}$ & $<0.001$ \\
\hline
\end{tabular}

insured $(62 \%, \mathrm{n}=27,246)$, those with a primary care physician $(61 \%, \quad n=27,731)$, widowed $(65 \%$, $\mathrm{n}=6,837)$ married $(61 \%, \mathrm{n}=13,827)$, those with a routine check-up in the last year $(62 \%, n=25,654)$, the retired $(66 \%, n=14,497)$, and those with an annual income level of $75,000+(62 \%, n=3,784)$.

The receipt of influenza vaccination was significantly lower among participants who could not see a doctor in the last year due to cost $(46 \%$, $n=2,634)$ and among everyday smokers (49\%, $n=2,463)$. The results indicated a significantly lower proportion of African Americans respondents receiving the influenza vaccination $(50 \%, n=3,533)$ when compared to Whites respondents $(61 \%$, $\mathrm{n}=24,915)$.

In the logistic regression model (Table 3), African Americans had significantly lower odds of receiving influenza vaccination when compared to Whites in the same strata for those who are 44 years or older, from both genders, all education levels, those with healthcare coverage, with or without having cost as a barrier to see the doctor, and with most employment status (the self-employed, students or those out of work for less than a year were not found statistically significant).

\section{DISCUSSION}

The CDC recommendations and the American Diabetes Association's standards of medical care for patients with diabetes include an annual influenza vaccination for all patients with diabetes over 6 months of age. ${ }^{5,16}$ Although the vaccination rates for adult diabetes patients from both races in this study $(60 \%, n=28,448)$ are higher than the national vaccination rates (41.5\%), 17 a large gap (even larger for African Americans) remains between the Healthy People 2020 goals (90\%) for 


\begin{tabular}{|c|c|c|c|c|}
\hline & Characteristic & Received vaccine & Did not receive vaccine & $\begin{array}{l}\text { Chi-square } \\
\mathrm{P} \text { value }\end{array}$ \\
\hline Total & & $28,448(60.17)$ & $18,835(39.83)$ & \\
\hline Race & $\begin{array}{r}\text { Whites } \\
\text { African Americans }\end{array}$ & $\begin{array}{c}24,915(61.92) \\
3,533(50.16)\end{array}$ & $\begin{array}{c}15,325(38.08) \\
3,510(49.84)\end{array}$ & $<0.001$ \\
\hline Age & $\begin{array}{r}18-34 \\
35-44 \\
45-54 \\
55-65 \\
65+ \\
\end{array}$ & $\begin{array}{c}307(39.41) \\
906(43.54) \\
3,095(49.81) \\
7,741(57.51) \\
16,399(66.26)\end{array}$ & $\begin{array}{c}473(60.59) \\
1,175(56.46) \\
3,118(50.19) \\
5,719(42.49) \\
8,350(33.74) \\
\end{array}$ & $<0.001$ \\
\hline Gender & $\begin{array}{r}\text { Male } \\
\text { Female }\end{array}$ & $\begin{array}{l}11,590(59.18) \\
16,858(60.86)\end{array}$ & $\begin{array}{c}7,993(40.82) \\
10,842(39.14)\end{array}$ & $<0.001$ \\
\hline Education & $\begin{array}{r}\text { High school graduate or less } \\
\text { Some collage or more }\end{array}$ & $\begin{array}{l}13,121(58.06) \\
15,327(62.10)\end{array}$ & $\begin{array}{l}9,479(41.94) \\
9,356(37.90)\end{array}$ & $<0.001$ \\
\hline General health & $\begin{array}{r}\text { Excellent } \\
\text { Very good } \\
\text { Good } \\
\text { Fair } \\
\text { Poor } \\
\end{array}$ & $\begin{array}{c}774(57.38) \\
4,649(60.98) \\
10,623(60.29) \\
8,095(59.86) \\
4,306(60.08) \\
\end{array}$ & $\begin{array}{c}575(42.62) \\
2,975(39.02) \\
6,996(39.71) \\
5,428(40.14) \\
2,861(39.92) \\
\end{array}$ & 0.128 \\
\hline Health care coverage & $\begin{array}{r}\text { Yes } \\
\text { No } \\
\end{array}$ & $\begin{array}{c}27,246(61.90) \\
1,202(36.84) \\
\end{array}$ & $\begin{array}{c}16,773(38.10) \\
2,062(63.16) \\
\end{array}$ & $<0.001$ \\
\hline Has a health care provider & $\begin{array}{r}\text { Yes } \\
\text { No } \\
\end{array}$ & $\begin{array}{c}27,731(61.09) \\
717(38.00) \\
\end{array}$ & $\begin{array}{c}17,665(38.91) \\
1,170(62.00) \\
\end{array}$ & $<0.001$ \\
\hline $\begin{array}{l}\text { Could not see a doctor in last } \\
12 \text { months due to cost }\end{array}$ & $\begin{array}{r}\text { Yes } \\
\text { No }\end{array}$ & $\begin{array}{c}2,634(45.59) \\
25,814(62.19)\end{array}$ & $\begin{array}{c}3,143(54.41) \\
15,692(37.81)\end{array}$ & $<0.001$ \\
\hline Last routine Check up & $\begin{array}{r}<12 \text { months } \\
>=1 \text { year }\end{array}$ & $\begin{array}{c}25,654(61.67) \\
2,794(49.16) \\
\end{array}$ & $\begin{array}{l}15,944(38.33) \\
2,8891(50.84)\end{array}$ & $<0.001$ \\
\hline Smoking status & $\begin{array}{r}\text { Everyday } \\
\text { Some days } \\
\text { Not at all }\end{array}$ & $\begin{array}{c}2,463(48.78) \\
852(54.79) \\
11,535(63.38) \\
\end{array}$ & $\begin{array}{c}2,586(51.22) \\
703(45.21) \\
6,664(36.62)\end{array}$ & $<0.001$ \\
\hline Marital status & $\begin{array}{r}\text { Married } \\
\text { Divorced } \\
\text { Widowed } \\
\text { Separated } \\
\text { Never married } \\
\text { Member of an unmarried couple }\end{array}$ & $\begin{array}{c}13,827(61.10) \\
4,519(57.07) \\
6,837(64.57) \\
566(49.26) \\
2,398(53.84) \\
301(55.54) \\
\end{array}$ & $\begin{array}{l}8,804(38.90) \\
3,400(42.93) \\
3,751(35.43) \\
583(50.74) \\
2,056(46.16) \\
241(44.46) \\
\end{array}$ & $<0.001$ \\
\hline Employment status & $\begin{array}{r}\text { Employed for wages } \\
\text { Self-employed } \\
\text { Out of work for }>1 \text { year } \\
\text { Out of work for more }<1 \text { year } \\
\text { A homemaker } \\
\text { A student } \\
\text { Retired } \\
\text { Unable to work }\end{array}$ & $\begin{array}{c}6,167(56.25) \\
1,021(48.97) \\
632(44.70) \\
357(43.59) \\
1,378(58.24) \\
84(48.00) \\
14,497(66.38) \\
4,248(56.56) \\
\end{array}$ & $\begin{array}{c}4,797(43.75) \\
1,064(51.03) \\
782(55.30) \\
462(56.41) \\
988(41.76) \\
91(52.00) \\
7,342(33.62) \\
3,262(43.44) \\
\end{array}$ & $<0.001$ \\
\hline The annual income level & $\begin{array}{r}\text { Less than } 10000, \\
10000-15000 \\
15000-20000 \\
20000-25000 \\
25000-35000 \\
35000-50000 \\
50000-75000 \\
\text { More than } 75000 \\
\end{array}$ & $\begin{array}{l}1,701(52.31) \\
2,408(57.05) \\
2,703(58.17) \\
3,114(59.36) \\
3,561(61.30) \\
3,832(61.85) \\
3,290(61.76) \\
3,784(62.08) \\
\end{array}$ & $\begin{array}{l}1,551(47.69) \\
1,813(42.95) \\
1,944(41.83) \\
2,132(40.64) \\
2,248(38.70) \\
2,364(38.15) \\
2,037(38.24) \\
2,311(37.92) \\
\end{array}$ & $<0.001$ \\
\hline
\end{tabular}

influenza vaccination rates among persons with diabetes and the current rates. ${ }^{8}$

Results from this study concur with a few previous studies which reported higher vaccination rates in Whites compared to African Americans individuals with diabetes ${ }^{11,18}$ with 3 important additions to current knowledge about disparities in influenza vaccination. First, this study reported a nonsignificant effect of income, last routine checkup, marital status, general health status, smoking status and having a personal doctor on racial disparities in vaccination rates. Second, age, gender, education, having a health care coverage, not being able to see a doctor in last year due to cost, and employment status were found to significantly modify the effect of race on influenza vaccination. Finally, even though vaccination rates for those aged 44 years or older increase significantly as age increases, the highest racial disparity in influenza vaccination for different age groups was found in the oldest age group (65+ years).

Even though previous studies reported a significant association between influenza vaccination and differences in income ${ }^{19-22}$, having a healthcare provider $^{23,24}$ marital status ${ }^{19,21,25}$, last routine checkup $^{22,26,27}$, general health status ${ }^{27-29}$ and smoking status ${ }^{26,27}$, none of these factors were found to have a significant effect on the racial disparity in influenza vaccine coverage in this study. However, these variables might contribute to this disparity by acting as mediators, which we did not account for.

Across all strata of gender, education, health care coverage, cost as a barrier to see a doctor, age of 


\begin{tabular}{|c|c|c|c|c|}
\hline \multicolumn{2}{|l|}{ Characteristic } & $\begin{array}{l}\text { Odds ratio*£ } \\
\text { (OR) }\end{array}$ & $95 \% \mathrm{Cl}$ & $P$ value \\
\hline Age & $\begin{array}{r}18-34 \\
35-44 \\
45-54 \\
55-65 \\
65+\end{array}$ & $\begin{array}{l}0.893 \\
0.763 \\
0.766 \\
0.703 \\
0.568\end{array}$ & $\begin{array}{c}0.515: 1.545 \\
0.517: 1.126 \\
0.604: 0.971 \\
0.591: 0.838 \\
0.484: 0.666\end{array}$ & $\begin{array}{c}0.684 \\
0.172 \\
0.028 \\
<0.001 \\
<0.001\end{array}$ \\
\hline Gender & $\begin{array}{r}\text { Female } \\
\text { Male }\end{array}$ & $\begin{array}{l}0.602 \\
0.638\end{array}$ & $\begin{array}{l}0.534: 0.680 \\
0.538: 0.755\end{array}$ & $\begin{array}{l}<0.001 \\
<0.001\end{array}$ \\
\hline Education & $\begin{array}{l}\text { High school graduate or less } \\
\text { Some collage or more }\end{array}$ & $\begin{array}{l}0.641 \\
0.623\end{array}$ & $\begin{array}{l}0.559: 0.736 \\
0.537: 0.723\end{array}$ & $\begin{array}{l}<0.001 \\
<0.001\end{array}$ \\
\hline Health care coverage & $\begin{array}{r}\text { Yes } \\
\text { No }\end{array}$ & $\begin{array}{l}0.631 \\
0.875\end{array}$ & $\begin{array}{l}0.568: 0.702 \\
0.636: 1.202\end{array}$ & $\begin{array}{c}<0.001 \\
0.408\end{array}$ \\
\hline Could not see a doctor in last 12 months due to cost & $\begin{array}{r}\text { Yes } \\
\text { No }\end{array}$ & $\begin{array}{l}0.685 \\
0.652\end{array}$ & $\begin{array}{l}0.538: 0.846 \\
0.582: 0.729\end{array}$ & $\begin{array}{c}0.002 \\
<0.001\end{array}$ \\
\hline Employment status & $\begin{array}{r}\text { Employed for wage } \\
\text { Self-employed } \\
\text { Out of work }>\text { a year } \\
\text { Out of work }<\text { a year } \\
\text { A homemaker } \\
\text { A student } \\
\text { Retired } \\
\text { Unable to work }\end{array}$ & $\begin{array}{l}0.665 \\
0.966 \\
0.523 \\
1.349 \\
0.502 \\
0.605 \\
0.552 \\
0.670\end{array}$ & $\begin{array}{l}0.543: 0.816 \\
0.523: 1.785 \\
0.337: 0.812 \\
0.725: 2.509 \\
0.301: 0.837 \\
0.189: 1.940 \\
0.467: 0.654 \\
0.562: 0.870\end{array}$ & $\begin{array}{c}<0.001 \\
0.913 \\
<0.001 \\
0.345 \\
0.008 \\
0.396 \\
<0.001 \\
0.001\end{array}$ \\
\hline
\end{tabular}

44 years or more, and employment status (except self-employed, student, and out of work for less than a year), Whites were more likely to be vaccinated when compared to African Americans.

The racial disparity of vaccination among different age groups was the highest in the oldest age group, this may be due to the fact that elderly participants (aged 65+ years) are the largest single group in the U.S who have limited health literacy abilities. ${ }^{30,31}$ Health literacy was found in previous studies to be associated with disparities between African Americans and Whites ${ }^{32-34}$; Whites' older adults were found to have an average health literacy score that was significantly higher than the average of African Americans older adults. ${ }^{32}$ Other potential explanations might be the documented differences in cultural beliefs, resistant attitudes, and seeking behavior in vaccination ${ }^{35,36}$ among African Americans' and whites' elderly that may not be as pronounced in later generations.

In the current study, racial disparities in receiving influenza vaccination were higher in those with health care coverage and those who did not report cost as a barrier to see a doctor in the last year. This highlights the importance of examining factors beyond access to care to explain the racial disparities in influenza vaccination rates between African Americans and Whites such as the differences in cultural values and health beliefs about vaccination and the consequences of its uptake.

Racial disparities among different employment groups were the highest among homemakers. This can be a target for future vaccination campaigns in order to foster the immunization equity among this population.

\section{Limitations and Strengths}

This study had both strengths and weaknesses. One of the limitations of this study was using the household-based survey (BRFSS) which limited our sample to include non-institutionalized adult individuals, living in households with a landline or cell phone only, so patients with diabetes who were hospitalized, staying in a long-term care facility or in hospice care or those who do not have a phone, were excluded from the study sample. Future studies may be necessary to include institutionalized patients with diabetes to identify specific predictors or racial disparities in influenza vaccination rates since reasons for disparities, if they exist, would be quite different.

BRFSS is a self-reported survey, which might be subject to recall bias. However, self-reporting about vaccination has been validated in prior studies. ${ }^{37,38}$ This study did not include all the factors that might predict the receipt of influenza vaccination such as quality of care, attitudes, preferences, beliefs, history of vaccination and patient-centered provider communication due to lack of this data in the BRFSS. Future studies might need to address such factors and assess their effects on the influenza vaccination rates in patients with diabetes.

This study's strengths include the benefits of using a nationally representative survey (BRFSS) with a large sample size that makes the results generalizable to the non-institutionalized adult population of patients with diabetes nationwide and provides a valuable image of the disparity between African Americans and Whites in this specific population. Additionally, there are few studies that looked at racial disparities in influenza vaccination among diabetes patients and factors contributing to this racial disparity. More studies might be beneficial to help increase the understanding and targeting of high-risk populations in order to increase their influenza vaccination rates.

\section{CONCLUSIONS}

This study found a significant racial disparity in influenza vaccination rates in adults with diabetes 
with higher rates in Whites compared to African Americans individuals.

The public health policies that target diabetes patients in general and specifically African Americans in the 65+ age group, women, and homemakers, may be necessary to diminish the racial disparity in influenza vaccination rates between African Americans and Whites diabetics.

\section{CONFLICT OF INTEREST}

Both authors certified that had no financial disclosure, commercial association or any conflict of interest whatsoever.

\section{VACUNACIÓN DE LA GRIPE EN PACIENTES CON DIABETES: DIFERENCIA DE PREVALENCIA ENTRE AFRO-AMERICANOS Y BLANCOS}

\section{RESUMEN}

Antecedentes: Los pacientes con diabéticos que contraen gripe están con mayor riesgo de complicaciones, tales como hospitalización y muerte. Los pacientes con diabetes tienen tres veces más de probabilidad de morir de gripe que los que no padecen diabetes. Las disparidades raciales entre pacientes con diabetes no han sido estudiadas con profundidad en los servicios de prevención de la salud.

Objetivo: Comparar las tasas de vacunación de gripe entre afro-americanos y blancos con diabetes e investigar los factores que pueden tener impacto en las diferencias raciales a la hora de vacunarse de gripe.

Métodos: Se realizó un análisis secundario de datos de 47.283 pacientes (no sopesados) con diabetes de la encuesta 2011 Behavioral Risk Factor Surveillance System (BRFSS) (15.902.478 sopesados). Se preguntó a los encuestados si habían recibido vacunación de gripe en los últimos 12 meses. Utilizamos una regresión logística para estimar la diferencia de probabilidad de recibir vacuna de la gripe basada en la raza.

Resultados: Los resultados indicaron que una proporción significativamente menos de respondentes afroamericanos $(50 \%)$ comunicaban que habían recibido vacuna de la gripe en el pasado año, en comparación con los respondentes blancos $(61 \%)$. Se encontró que edad, género, educación, cobertura sanitaria, costes de cuidados de salud, y estado laboral modificaban significativamente el efecto de la raza para recibir vacunación de gripe. Conclusiones: Este estudio encontró una diferencia racial significativa en las tasas de vacunación de gripe en adultos con diabetes, con tasas mayores en los blancos que en los afro-americanos. Para disminuir las diferencias raciales en la vacunación de gripe entre blancos y afro-americanos, las políticas de salud pública deberían apuntar a los pacientes con diabetes, y especialmente a los afro-americanos en el grupo etario de 65 o más años, mujeres, y amas de casa

Palabras clave: Vacunas contra la Gripe; Vacunación; Diabetes Mellitus; Disparidades en Atención de Salud; Grupos Étnicos; Promoción de la Salud; Encuestas de Atención de la Salud; Estados Unidos

1. Centers for Disease Control and Prevention. Seasonal influenza. http://www.cdc.gov/flu/about/qa/disease.htm (Accessed Sep 25, 2013).

2. Centers for Disease Control and Prevention. Estimates of deaths associated with seasonal influenza --- United States, 1976-2007 MMWR Morb Mortal Wkly Rep. 2010;59(33):1057-1062.

3. World Health Organization. Influenza overview. http://www.who.int/mediacentre/factsheets/2003/fs211/en/ (Accessed Sep 25, 2013).

4. Molinari NA, Ortega-Sanchez IR, Messonnier ML, Thompson WW, Wortley PM, Weintraub E, Bridges CB. The annual impact of seasonal influenza in the US: Measuring disease burden and costs. Vaccine. 2007;25(27):5086-5096. doi: 10.1016/j.vaccine.2007.03.046

5. Centers for Disease Control and Prevention. Flu and people with diabetes . http://www.cdc.gov/flu/diabetes/index.htm (Accessed Sep 20, 2013).

6. Centers for Disease Control and Prevention. Diabetes \& flu: What you need to know and do. http://www.cdc.gov/diabetes/news/flu.htm (Accessed Sep 21, 2013).

7. U.S. Department of Health and Human Services. Disparities. http://www.healthypeople.gov/2020/about/DisparitiesAbout.aspx (Accessed Sep 20, 2013).

8. U.S. Department of Health and Human Services. Healthy people 2020. Immunization and infectious diseases. http://www.healthypeople.gov/2020/topicsobjectives2020/objectiveslist.aspx?topicld=23 (Accessed Sep 15, 2013).

9. Ompad DC, Galea S, Vlahov D. Distribution of influenza vaccine to high-risk groups. Epidemiol Rev. 2006;28:54-70. doi: 10.1093/epirev/mxj004

10. Linn ST, Guralnik JM, Patel KV. Disparities in influenza vaccine coverage in the united states, 2008. J Am Geriatr Soc. 2010;58(7):1333-1340. doi: 10.1111/j.1532-5415.2010.02904.x

11. Egede LE, Zheng D. Racial/ethnic differences in influenza vaccination coverage in high-risk adults. Am J Public Health. 2003;93(12):2074-2078

12. Clancy U, Moran I, Tuthill A. Prevalence and predictors of influenza and pneumococcal vaccine uptake in patients with diabetes. Ir Med J. 2012;105(9):298-300.

13. Centers for Disease Control and Prevention. Behavioral risk factor surveillance system , 2011 survey data and documentation . http://www.cdc.gov/brfss/annual_data/annual_2011.htm (Accessed July 20, 2013).

14. Centers for Disease Control and Prevention. Behavioral risk factor surveillance survey, 2011 summary data quality report. . http://www.cdc.gov/brfss/pdf/2011_Summary_Data_Quality_Report.pdf (Accessed July 12, 2013).

15. Stafford KA, Sorkin JD, Steinberger EK. Influenza vaccination among cancer survivors: Disparities in prevalence between blacks and whites. J Cancer Surviv. 2013;7(2):183-190. doi: 10.1007/s11764-012-0257-3 
16. American Diabetes Association. Standards of medical care in diabetes-2009. http://care.diabetesjournals.org/content/32/Supplement_1/S13.full (Accessed Sep 29, 2013).

17. Centers for Disease Control and Prevention. Flu vaccination coverage, united states, 2012-13 influenza season. 2013.

18. Egede LE, Zheng D. Racial/ethnic differences in adult vaccination among individuals with diabetes. Am J Public Health. 2003;93(2):324-329.

19. O'Malley AS, Forrest CB. Immunization disparities in older americans: Determinants and future research needs. Am $\mathrm{J}$ Prev Med. 2006;31(2):150-158. doi: 10.1016/j.amepre.2006.03.021

20. Mangtani P, Breeze E, Stirling S, Hanciles S, Kovats S, Fletcher A. Cross-sectional survey of older peoples' views related to influenza vaccine uptake. BMC Public Health. 2006;6:249. doi: 10.1186/1471-2458-6-249

21. Peña-Rey I, Pérez-Farinós N, Sarría-Santamera A. Factors associated with influenza vaccination among elderly spanish women. Public Health. 2004;118(8):582-587. doi: 10.1016/j.puhe.2004.04.010

22. de Lataillade C, Auvergne S, Delannoy I. 2005 and 2006 seasonal influenza vaccination coverage rates in 10 countries in africa, asia pacific, europe, latin america and the middle east. J Public Health Policy. 2009;30(1):83-101. doi: 10.1057/jphp.2008.40; 10.1057/jphp.2008.40

23. Winston CA, Wortley PM, Lees KA. Factors associated with vaccination of medicare beneficiaries in five U.S. communities: Results from the racial and ethnic adult disparities in immunization initiative survey, 2003. J Am Geriatr Soc. 2006;54(2):303-310. doi: 10.1111/j.1532-5415.2005.00585.x

24. Figaro MK, Belue R. Prevalence of influenza vaccination in a high-risk population: Impact of age and race. J Ambul Care Manage. 2005;28(1):24-29.

25. Damiani G, Federico B, Visca M, Agostini F, Ricciardi W. The impact of socioeconomic level on influenza vaccination among italian adults and elderly: A cross-sectional study. Prev Med. 2007;45(5):373-379. doi: 10.1016/j.ypmed.2007.07.007

26. Sarría-Santamera A, Timoner J. Influenza vaccination in old adults in Spain. Eur J Public Health. 2003;13(2):133-137.

27. de Andres AL, Garrido PC, Hernandez-Barrera V, Del Pozo SV, de Miguel AG, Jimenez-Garcia R. Influenza vaccination among the elderly spanish population: Trend from 1993 to 2003 and vaccination-related factors. Eur J Public Health. 2007;17(3):272-277. doi: 10.1093/eurpub/ckl242

28. Shemesh AA, Rasooly I, Horowitz P, Lemberger J, Ben-Moshe Y, Kachal J, Danziger J, Clarfield AM, Rosenberg E. Health behaviors and their determinants in multiethnic, active israeli seniors. Arch Gerontol Geriatr. 2008;47(1):63-77. doi: 10.1016/j.archger.2007.07.001

29. Telford R, Rogers A. What influences elderly peoples' decisions about whether to accept the influenza vaccination? A qualitative study. Health Educ Res. 2003;18(6):743-753.

30. Kutner M, Greenberg E, Baer J. Adult literacy in america: A first look at the findings of the national adult literacy survey. Washington, DC: National Center for Educational Statistics; 2005.

31. White S. Assessing the nation's health literacy: Key concepts and findings of the national assessment of adult literacy (NAAL) Chicago, IL: American medical association foundation; 2008.

32. Bennett IM, Chen J, Soroui JS, White S. The contribution of health literacy to disparities in self-rated health status and preventive health behaviors in older adults. Ann Fam Med. 2009;7(3):204-211. doi: 10.1370/afm.940

33. Sentell TL, Halpin HA. Importance of adult literacy in understanding health disparities. J Gen Intern Med. 2006;21(8):862-866. doi: 10.1111/j.1525-1497.2006.00538.x

34. Howard DH, Sentell T, Gazmararian JA. Impact of health literacy on socioeconomic and racial differences in health in an elderly population. J Gen Intern Med. 2006;21(8):857-861. doi: 10.1111/j.1525-1497.2006.00530.x

35. Zimmerman RK, Santibanez TA, Janosky JE, Fine MJ, Raymund M, Wilson SA, Bardella IJ, Medsger AR, Nowalk MP. What affects influenza vaccination rates among older patients? an analysis from inner-city, suburban, rural, and veterans affairs practices. Am J Med. 2003;114(1):31-38. doi: S0002934302014213

36. Hebert PL, Frick KD, Kane RL, McBean AM. The causes of racial and ethnic differences in influenza vaccination rates among elderly medicare beneficiaries. Health Serv Res. 2005;40(2):517-537. doi: HESR370

37. Shenson D, Dimartino D, Bolen J, Campbell M, Lu PJ, Singleton JA. Validation of self-reported pneumococcal vaccination in behavioral risk factor surveillance surveys: Experience from the sickness prevention achieved through regional collaboration (SPARC) program. Vaccine. 2005;23(8):1015-1020. doi: 10.1016/j.vaccine.2004.07.039

38. Zimmerman RK, Raymund M, Janosky JE, Nowalk MP, Fine MJ. Sensitivity and specificity of patient self-report of influenza and pneumococcal polysaccharide vaccinations among elderly outpatients in diverse patient care strata. Vaccine. 2003;21(13-14):1486-1491. 